\title{
LIFE WRITING ACROSS GENRES AND AT THE INTERSECTIONS OF ALTERITY
}

\author{
Guest Editors: \\ Maria Rita Drumond Viana ${ }^{1^{*}}$ \\ ${ }^{1}$ Universidade Federal de Santa Catarina, Florianópolis, SC, Brasil \\ Renata Lucena Dalmaso ${ }^{2 *}$ \\ ${ }^{2}$ Universidade Federal do Sul e Sudeste do Pará, Marabá, PA, Brasil \\ Juliana Borges Oliveira de Morais ${ }^{3 * * *}$ \\ ${ }^{3}$ Universidade Federal de São João Del-Rei, São João Del-Rei, MG, Brasil
}

Life writing, the topic of this special issue of Ilha do Desterro, has to do with the personal. Life writing, or escritas de vida as this issue is called in Portuguese, appears in many forms, since the way we tell stories about ourselves is as diverse as what this self might look like. Diverse as life writing may be, though, it relies on certain common threads in its weaving of lives through writing: self, truth, and memory.

The first thread speaks of the prime subject of life writing: the self. Sidonie Smith and Julia Watson (2001) define life writing "as a general term for writing of diverse kinds that takes a life as its subject" (3), a rather broad definition that encompasses many manifestations but keeps the focus on a given person's life at the core of the concept. The processes through which this self is constituted precisely through life writing are seen by scholars such as G. Thomas Couser as integral to identity forming. Rather than reflecting a pre-established and fixed

\footnotetext{
" Professor D2 at the Department of Foreign Languages and Literatures (DLLE), Universidade Federal de Santa Catarina and a permanent member of the Postgraduate Programmes in English and in Translation Studies (PPGI and PGET). Her main research interests can be found at the intersection of the study of life writing, translation studies and book history. She was elected a visiting doctoral student at the Oxford Centre for Life Writing in 2013-14 and a member of Wolfson College in order to conduct research on the public letters of W. B. Yeats. She was one of the translators into Brazilian Portuguese of Roger Casement's Amazon Diaries (2016) as well as Virginia Woolf's On Being Ill (2021). E-mail: mritaviana@gmail.com ORCID: https://orcid.org/00000002-1985-3375.

** Professor at the Universidade Federal do Sul e Sudeste do Pará (Unifesspa, Brazil). Her research interests include graphic memoirs, life writing, representations of disability, queer theory, and feminisms. She is a twice Fulbright awardee, having received a Fulbright Dissertation Award to study at the University of Michigan (Ann Arbor, USA), and, more recently, a Junior Faculty Award, which allowed her to conduct research at George Washington University, in Washington D.C., on the field of disability and graphic memoirs. E-mail: rldalmaso@ gmail.com ORCID: https://orcid.org/0000-0001-5049-9434.

${ }^{* * *}$ Professor at the Department of Letters, Arts and Culture at Federal University of São João del-Rei - Minas Gerais, where she teaches Literatures in English and Literary Theory. She holds a Master's Degree in Literatures in English and a Ph.D. in Literary Theory and Comparative Literature, both from the Federal University of Minas Gerais. Her research interests are literatures written by women, contemporary literatures of the African diaspora and literary literacy. E-mail: jubmorais@gmail.com. ORCID: https://orcid.org/0000-0003-2093-7258.
} 
subject, life writing functions as a "means by which selves are constituted in the first place, ... a means by which nearly all people develop their identities and personalities early in life" $(2012,25)$. From childhood, we engage in narratives about the self as a form of identity practice, one that we conjure up as adults as well, as John Paul Eakin points out $(2017,272)$. Self-referentiality is an integral part of what makes us who we are, how we present ourselves to the world, and how others perceive us. Beyond that, writing of the self is key in the very production of that ever-evolving self. The self is, thus, both a source material and a consequence of life writing practices, as identity can be formed through the writing process.

The second thread - truth - grounds, albeit sometimes loosely, the different types of accounts of the self to lived experiences as opposed to fiction. Life writing, for Couser, is "the umbrella term used to refer to all nonfictional representation of identity" (24). The nonfictional is a key factor here, for it proposes a distinction between fictional storytelling and life writing. Whatever form life writing may take, it is necessarily associated (even if that association appears contingent with other factors) with the truth, or at least the semblance of it. The implication of veracity can take on the form of a pact, as proposed by Philippe Lejeune $(1989,4)$, which ties the ideas of identity and truth-telling to life writing. Of course, since its original proposition by the French theorist of autobiography, the definition of the truth within life writing is a frequent topic of debate among scholars and enthusiasts of the genre.

Life writing is as much about the truth as it is about discourses of the truth. Attitudes towards the perceived truthfulness of life writing texts vary across different cultures and ages, as the weight given to certain factors such as the correspondence between the name of the author to that of the protagonist, social status of the author, textual genre, and media also shifts. One's relation to the concept of nonfictional is, thus, highly contextual. Some authors even take advantage of the fluidity of these discourses of the truth, playing with the notion of fictionality in their own life writing. We can see this playfulness with the truth in memoirs such as Alison Bechdel's Fun Home: A Family Tragicomic and Jeanette Winterson's Why Be Happy When You Can Be Normal, to name just a couple of examples that explicitly tackle the inadequacy of arriving at an objective truth in an account of their own lives.

These discourses of truth may favour certain subjects while disregarding others, reproducing social hierarchies, for example. Marginalized writers undergo a much more careful scrutiny, often having to prove their claim to the truth in ways that privileged authors do not. Incidents in the Life of a Slave Girl: Written by Herself, by Harriet A. Jacobs, for example, was at the time of its publication, 1861, discredited as a fraud for the fictionalization of names in the narrative (Smith and Watson 30). The thing to ask here is in what context is identity being constructed, or who gets to write about themselves, and how do truth discourses work to disavow or enable the selves being produced through life writing.

The third thread, memory, materializes the connection between the self and the past. Memory creates a narrative of the past for the subject, situated 
in the present. Life writing depends on memory to create meanings of the self, for, as Smith and Watson argue, "memory is thus both source and authenticator of autobiographical acts" (16). Even though memory is fragmented and noncohesive at times, it is seen as a link between past and present selves.

The relation between truth and memory can be complicated at best, viciously contentious at worst. Truth discourses are intrinsically intertwined to the authoritative aura of memory in life writing. Memory, however, is notoriously deceptive, fragmented, disrupting the naturalized assumption of the reliability. On the one hand, one's own memory can be deceiving - think of early childhood memories and how they are often composed from other people's accounts of the events rather than one's own eye-witness perspective. Sometimes even the most vivid memory is simply not reliable, and some life writing texts acknowledge that (on occasion).

On the other hand, certain subjects' memories are deemed less reliable than others, depending on that person's social status in a given society. Leigh Gilmore points out, for example, that testimony from women is frequently discredited through an "historical association of race and gender with lying" $(2017,2)$. A woman's memory of events, especially an account of a woman of colour, is not seen as reliable, especially if confronted with a white male's version of the same incident. The authority we assign to a person's memory is, thus, contingent to her status in society.

Although memory is usually associated with an individual's recollection of events in the past, it can also be derived from collective experiences. Collective memory stems from the ways communities rely on shared experiences and remembering practices to preserve their history. Focusing on indigenous communities, Juliana Salles argues in this issue that collective life writing is a recurrent characteristic of works such as The Falling Sky: Words of a Yanomami Shaman, I, Rigoberta Menchú: an Indian Woman in Guatemala and Bobbi Lee: Indian Rebel Struggles of a Native Canadian Woman. These texts combine elements of autoethnography and ecobiography to constitute a subgenre of life writing that she refers to as indigenous life narratives. Collective memory is a hallmark of these texts that combine personal and communal history in their narratives.

Memory is also developed from a previous generation's account of events, referred to by Mariane Hirsch as postmemory $(1996,662)$. Hirsch references postmemory in relation to children of Holocaust survivors, but the term is also used to refer to other instances where the impact of trauma in their parents' lives generates its own kind of memory. Postmemory is, thus, at once distanced and close to trauma. While the experience is not lived directly by this second generation, the memory is relived through recollection by others and through their own imagination.

The connection between self, truth, and memory is, thus, woven in complicated turns and spins that make up life writing. In this issue, we have tried to take a broad and inclusive approach to the genre, considering articles whose corpora dealt with auto/biographies, letters, memoirs, journals, and diaries, as well as hybrid forms that mixed them sometimes with avowedly fictional 
narratives. We have tried to incorporate the possibilities of life writing into the scope of the issue, hoping to arrive at a selection of articles that embodies the infinite variety of the concept.

As researchers of life writing, the personal not only informs our object of study, but also how we like to approach the discipline: personally. The praxis of life writing requires such commitment. This was an issue entirely organized during the COVID-19 crisis, the reconstruction of the issue's memory necessarily dives into the repercussions of the enforced isolation. That memory is composed of virtual meetings that began and ended with personal narratives of coping with the spectrum of the pandemic in our lives, particularly in Brazil, where all three of us are located. There were a number of losses along the way. We have lost loved ones, colleagues, friends, and students to this disease and to the way it was mishandled by our government. We have also felt on our own bodies the burden of those absences added to the increasing workload of virtual life. More than editors, we have had to rely on each other as friends for support throughout this editorial process. The issue carries that memory, along with those of the authors' and reviewers' that have also endured the submission and revision processes during the pandemic.

This special edition on life writing is structured in two main axes: the first, "Life Writing Across Genres" reflects on how this concept opens up possibilities for transgeneric and hybrid forms of writing in the study of literature. The section opens with Sean A. McPhail's consideration of Siegried Sassoon's Memoirs of George Sherston, whose status as fiction has long been debated. McPhail identifies in the compositional history of the three volumes in relation to some of its source materials (not only Sassoon's diaries but his own poetry) by contrasting "authority" and "authenticity" in the memoirs themselves. The article that follows it, "Confounding Lethe in the Moyola," written by Eugene O'Brien, focuses on how another poet, Seamus Heaney, reflects on his past and the literary tradition he subscribes to when writing the sequence "Route 101" from his last volume of poetry, Human Chain (2010). Employing the symbol of the tessera, a Roman large-scale mosaic, the author suggests that a transcendental pattern of life writing can be perceived when the poetic sequence - the original Aeneid the young Heaney reports buying in the poem, and Heaney's posthumously published translation of Book VI of the Aeneid - is examined together. Another mosaic is brought to consideration in Kristin Czarnecki's "A Living Mosaic of Human Beings:' The Life Writing of Virginia Woolf and Zitkala-Ša"' when the literary self-portraits composed by the two life writers are put in contact. Czarnecki considers the ethics of comparative approaches before revealing how a side-by-side study of Woolf and Zitkala-Ša can highlight instigating aspects of one another, particularly where race, class, and gender meet. Ana Carolina Mesquita's article can be seen to pick up from where Czarnecki left by probing deeper into the waters of Woolf's "Sketch of the Past." In her piece, Mesquita finds occurrences of fish and fishing imagery across the author's oeuvre in an attempt to conceptualise how the body experiences and relates memory in the 
retrospective glance afforded by the autobiographical sketch. Memory and its equivocations are at the centre of the next entry, an imaginary dialogue between its main author and another version of himself, as "they" consider the dissonance of past and present in a process found to be a parallel of self-translation. Evading some of the questions the interviewing ego makes, the author develops the idea of the othering of oneself in the workings of memory and life writing, with recourse to a variety of theorists from Brazil and abroad. The last three pieces in this axis consider the complexities of the autobiographical novel and of the alter-ego in three authors of the twentieth century: Zelda Fitzgerald, John Fante and Anaïs Nin. They each consider how what is hidden and what is laid bare can reveal about these authors' projects for their creative prose.

The second axis, "Intersections of alterity" interrogates how the practice of life writing can be developed as the crossroads of the many lines that can divide its subjects. Matters of nationality, race, ethnicity and language, migrant cultures, gender, and religion are addressed as the authors interrogate the affordances of life writing in different texts and media. The section opens with a reassessment of Lady Callcott's memoirs of Imperial Brazil and her redress of the muchmaligned first empress Leopoldina. Júlia Braga Neves argues that the unfinished manuscript Life of Don Pedro contains a sketch of the imperial family that, differently from previous assessments, is not based only on self-justification but constitutes a canny assessment of the complex and tangled relationships in the palaces' domestic lives. The temporal distance from the better-known Journal of a Voyage to Brazil, published in 1824, and the sketch is seen as context for some of the differences noticed, as the relationship between the English writer and the empress evolved. In "Contending Discourses of Black Autobiography," Anthony S. Foy places autobiographical discourses put forward by Black men in the United States in the context of the different demands of class, race, and gender struggles. Particularly in relation to the demands of respectability as a Black middle-class emerged during Jim Crow, Foy seeks in the works of "disreputable figures" the intersections that interrogate racialized, class-bound, and phallocentric autobiographical productions. The two articles that follow it zoom into the lesser known native communities of the Adivasi and the Yanomani, respectively. The first considers two narratives by women writers from Goa first published by Alito Siqueiras (in whose memory the article is written) in his blog Hany Konn and later collected for print publication in 2019. The authors expand the concept of "postmemory" to explore how these contemporary life writers inscribe certain experiences that precede their birth in the ways they narrate their present, particularly the effects of colonization and their othering as a lowcaste community. In the second article, Juliana Salles considers The Falling Sky: Words of a Yanomami Shaman (2015) as part of the wider ethnographic trend she identifies in the earlier works of Bobbi Lee (1975) and Rigoberta Menchú (1992), which would include narration by indigenous women and a later work of transcription, edition and translation by the publication writers, typically white. Another kind of survival and bid for expression is to be found in Jonas Mekas's 
oeuvre, the object of Barbara Cristina Marques's article. A Lithuanian survivor of the Second World War, Mekas wrote a number of diary entries that were collected in a book for publication in 1991 and which are here considered in relation to his filmic work, in particular Lost Lost Lost from 1976. Marques conceptualizes Mekas's ample cinematic output as film-diaries, a way to resist the mainstream forms of film privileged by the industry. The War and the Holocaust are also central to Mail Marques de Azevedo's comparison of Primo Levis The Drowned and the Saved (1986) and the fictionalized account of the bombing of Dresden in Kurt Vonnegut's Slaughterhouse-Five, which Vonnegut witnessed when taken as a prisoner of war in Germany in 1945.

Written as a letter, the three authors of the next article consider not only the testimonial value of letters but also their relationship with secrecy and intimacy, before reverting to Maya Angelou's Letter to my Daughter (2008) as a kind of collective life writing of Afrodiasporic subjects. The last piece is also concerned with writers' correspondences, this time not as a letter-manifesto such as Angelou's, but as what can be seen as the most intimate kind of letter-writing: the letter sent to a lover. Not exactly love letters in the more platonic conception of the word, James Joyce's correspondence with Nora Barnacle is analysed by Rangel Gomes de Andrade and Adalberto Luis Vicente in how they create a scene for Joyce to perform the literary figures of, first, the outsider, and then the dandy, as personae for a kind of epistolary enunciation inspired by romantic and symbolist aesthetics that preceded him and led the way for his reinvention of himself. For the authors, the figuration as an outsider is very much imbued with Joyce's sense of alterity from the dominating Catholicism of his Irish upbringing and becomes particularly relevant to him as he moves from his exile in continental Europe to visit Ireland, from where he writes to his lover, Nora.

The reviews included in this issue also consider different forms of life writing and how they are theorised and practised. Marília Leite evaluates one of the most important, multiauthored volume on diaries published recently, the Ben-Amos edited The Epic of Everyday Life (2020), whose contributors include most of the best-known scholars currently active in the English language and others. Translated into Brazilian Portuguese in 2018 as Afiadas, Michelle Dean's Sharp: Women Who Made an Art of Having an Opinion is an anthology with the biographies of ten women along its 416 pages, and manages, according to the reviewer, to mix biography and cultural history to introduce these feminist figures to Brazilian audiences, even if further care could be taken with explanatory notes. The last review, by Gabriela Zetehaku Araújo, is a careful examination of one of 2020's most awaited biographies, Heather Clarke's Red Comet: The Short Life and Blazing Art of Sylvia Plath. Araújo sees in Clarke's careful reading of archival material (a lot of which, despite being available, had not been studied in a concerted manner) one of the main reasons for having achieved the biographer's stated aim of seeing Plath as an artist.

Heather Clarke, when promoting Red Comet, has said more than once that she wanted to give Plath "the Hermione Lee treatment." There is no better 
way to conclude this issue than with an interview of two of the most influential biographers still active: R. F. Foster and Dame Hermione Lee herself, to whom the guest-editor Maria Rita Drumond Viana asked some rather long questions in "The Discipline of Life Writing: Two Arch-Biographers Reflect on their Careers."

We hope with this special issue to highlight life writing as a prolific field of study and encourage more scholars, particularly in Brazil, to pursue research in this area.

\section{Works Cited}

Bechdel, Alison. Fun Home: A Family Tragicomic. Houghton Mifflin, 2006.

Couser, G. Thomas. Memoir: An Introduction. Oxford University Press, 2012.

Eakin, John Paul. "Does Autobiography Have a Future?" Auto / Biography Studies, vol. 32, no. 2, 2017, pp. 271-73.

Gilmore, Leigh. Tainted Witness: Why We Doubt What Women Say About Their Lives. Columbia University Press, 2017.

Hirsch, Marianne. "Past Lives: Postmemories in Exile." Poetics Todays, vol. 17, no. 4, 1996, pp. 659-86.

Jacobs, Harriet. Incidents in the Life of a Slave Girl: Written by Herself. Penguin Books, 2000.

Lejeune, Philippe. "The Autobiographical Pact." On Autobiography, translated by Katherine Leary, University of Minnesota Press, 1989, pp. 3-30.

Smith, Sidonie, and Julia Watson. Reading Autobiography: A Guide for Interpreting Life Narratives. University of Minnesota Press, 2001.

Winterson, Jeanette. Why Be Happy When You Could Be Normal? Grove Press, 2011. 